\title{
Maths: from distance to e-learning
}

\author{
D. Álvarez, D. Moreno, P. Orduna, V. Pascual and F. J. San Vicente \\ Universidad Internacional de la Rioja, UNIR, y RedCultural-Kutursarea, Spain
}

\begin{abstract}
New technological progress and especially the use of Internet have implied a new paradigm on education, and nowadays one of its most prominent features is the rise of a new approach based on an instruction beyond the solid walls of schools and characterized by mobility. That is, e-learning. However, its origins and concept can be traced in time. This paper, focused on mathematics, deals with its evolution, antecedents and present status.
\end{abstract}

Keywords - e-learning and b-learning, History distance learning, Maths competencies and Maths software and platforms.

\section{INTRODUCTION}

$\mathrm{V}$

IRTUAL Education: A new learning concept.

Louis Hector Berlioz said once: "Time is a great teacher, but unfortunately it kills all its pupils". How do we understand urgency? Distance? Nowadays' need of reach? Distance education is not contemporary, not even new. This type of learning in which pupils do not need to go to in-person classrooms or schools has been a fact since almost the very first education systems in mankind history. However, nowadays, there is something else new. Time, so respected by the French composer from the 19th century, has become more valuable if possible. Moreover, time is asked to be more flexible in its daily use. Similarly, the idea of distance has changed. The Euclidean space that equals to the length of a straight line has lost its raison d'etre. In our society distance education lies in a virtual space through E-Learning. It has generated new values to measure time-space: the already mentioned time flexibility, globalization in the reach of education, costs decreases or fast teacher-student feedback...

In that new education context, it might be Urania who, jealous of Clio, wanted to stop being an exact science to widen its didactic understanding boundaries and, like History, make mathematics more versatile within a new educational paradigm. As Fernández-Mayoralas mentions, Gödel's theorems or fractal geometry blurred, lots of decades ago, the division between "sciences" and "humanities" [1 pp. 275-309]. However, in the time being, Mathematics might be using them and the humanistic conception of teaching to fit them again into the virtual educational world. Diatribes aside, according to Quinn, we should understand E-Learning as a "macro concept" with a short but intense history in terms of chronology. As that author said, "E-Learning is the macro concept that includes the mobile and online learning environments" [2]. Therefore, this new pedagogical mosaic consists of dozens of conceptual tiles that perform individually, but who all together form a renovating whole with its own contrasts.

The origin of that history of virtual change and transformation in education occurred outside networks and computers. As it has already been mentioned, in places where teacher-pupil distances were big, communication always looked for an artful way to develop itself. Thus, for instance, in the Australian Outback -also known as the "never never" desert- lessons were given through radio, from the small Alice Springs to the farms that were hundreds of kilometers far away. Besides, teachers visited their pupils by small airplanes once or twice a year [3 pp. 126-128].

After the first generation of distance teaching that would turn into paper, radio or television, new and fast evolution and perfection models would arise. The already mentioned first generation was developed between 1890 and the early 1970s. Nevertheless, following generations were very quickly established [4 pp. 217-219]. Thus, straddling those generations, we find Craft-Learning. Such system is based on teaching and training processes according to face-to-face classroom education with different communications through audio or videoconferences. As we can see, there have already been included elements from the second generation: video, tapes... That is the well-known "multimedia learning" [5 p. 57]. As far back as 1989-1999, the Uruguayan Edison Enrique Reina designed a new Home Learning (H-Learning) model with an IBM S/36 System. That method is still used and includes two activity sections: in-home lessons (school hours at home) and working and tutoring section, either in situ or face-to-face (FTF) with a simultaneous virtual presence. This pattern creates "personal learning environments" and, at the same time, brings together partial attendance courses and virtual learning [6]. That system is clearly connected to the one that would arise from the third generation of distance education or "telematic education". This one consists of a mixed education system called Blended learning or B-Learning [7 pp. 71-72] [8 p. 82]. Between 1985 and 1995 -when internet started to become public- that education system tried to combine again face-to-face learning with an emerging, but still uncertain, online learning. Therefore, it introduced into the learning models not only audiovisual media but also software designed to develop online courses. Actually, the usual face-to-face classroom model moved to the student's remote location. Obviously, it existed certain educator-student interaction, but the format was still "teachercentered" and provided little feedback [5 p. 58].

The deficiencies of the already mention first stages started to be fixed from the mid-1990s thanks to the development of the full virtual learning or E-Learning. In that moment, as a fourth generation, studenttutor or student-teacher feedback became constant. Its interaction reaches forums, e-mail, wiki environments, chats, blogs, etc. [5 p. 58]. Then, we can talk about internet education. A kind of education that did not get stuck in a -virtual- space that embraces plenty of activity and that, besides, continued evolving in the last decade towards the Web 2.0 [9]. However, the path it was taking went beyond that level and moved towards the "3.0 non-browser" environment. New terms such as semantic web, cloud or the visual-spatial concept of the virtual 3D world would end up surrounding E-Learning. Such progress allows us to talk about an education that is not only detached from the classroom but also from a specific geographical area. In other words, it is an "immersive education" [10]. The device has been "released" -wireless- from the static terminal network to become mobile. It is in that point when the fifth and last generation of distance education begins, thanks to Mobile Learning (ML) and U-Learning [11 p. 264] [12 pp. 95-96] [13 pp. 23-24]. Since 2005, these options have allowed flexible learning in terms of location and timing factors. They offer a more automatized and direct communication through different database systems or simulations in virtual reality spaces [5 p. 58]. Thus, if ML allows us to access our learning material through mobile phones or tablets, U-Learning opens the doors to educational activity areas in a "ubiquitous reality" with an even non-existent space [14] [15 pp. 125-127]. Moreover, it has allowed the development of new and very accessible teaching spaces within the OER -Open Educational 
Resources-, for instance, the OCW -Open Course Ware- or the MOOC -"Massive Open Online Course"- for Universities [16] [17] [18] [19] [20] [21].

At the conceptual level, education in virtual spaces -the E-Learning macro concept- should not be a mere bazaar of pedagogical terminology at the service of the user. Such reality should not be understood as a miscellaneous market with more or less new didactic techniques. A new epistemological idea arises before us, where knowledge must sail between the sea of the old truths and that of the new beliefs. We are offered a new Educational Paradigm, in capital letters. In it, every discipline -such as Mathematics- must have space and place to develop. It is not, or at least should not be, a confrontation between the inappropriately called "traditional education" and "the new teaching ways". In contrast, it should be understood as part of a historical and evolutionary continuum. It is true that, until now, a distinction between "virtual" and "distance" education has been made [22 p. 90] [4 p. 220]. Its evolution has adapted to a cultural moment and era. In such context of teaching in the "virtual space", the didactics of human and exact sciences should start to settle. That is a path that, as we will see, Urania, the muse of Mathematics in old times, has taken so far.

\section{From ANALOGICAL TO DIGITAL EDUCATIONAL TECHNOLOGY}

As with many other disciplines, the origins of knowledge and learning of mathematics are lost in the mists of time and in fact both must be linked to the very human nature. In this way, as Bernard Duvillié said human being can be qualified as an Homo Mathematicus given that mathematical lore is accumulative on human society from its very beginning as it's illustrated by evidence from prehistoric and ancient societies [23] [24, p. 38]. Regarding the Greek experience, the precise term of mathematics is $\mu \alpha \theta \eta \mu \alpha \tau 1 \kappa \eta$ and it's derived from the noun $\mu \alpha \dot{\theta} \eta \eta$ which means learning or knowledge, implying the intimate conscience and deep importance of this field in ancient thought. As Plato said arithmetic, geometry and algebra "make people more useful to themselves, and more wide awake; and again in measurements of things which have length, and breadth, and depth, they free us from that natural ignorance of all these things which is so ludicrous and disgraceful" [25]. In fact, Greek mathematical knowledge wasn't at all set apart from philosophy and although basic mathematical teachings were taught on the primary level of education, complex mathematics were studied in the highest intellectual centers of antiquity as Plato's Academia, Aristotle's Lyceum or the Library of Alexandria [26, pp. 13178] [27] [28, pp. 28-147] which were functioning until Christianism closed them. Certainly, distance learning wasn't a concept assumed in the Ancient and Medieval periods. However there was in Antiquity a kind of distance teaching in epistolary as letters were in some cases "assumed for teaching or instruction" [29, p. 5] between educators in any known discipline and pupils or enthusiasts, or were just written like a simple approach to knowledge's dissemination [30]. In this way, the letters addressed to the physicist and philosopher Hipatia by her disciple the bishop and poet Synesius of Cirene in the fifth century A.D. are deeply stimulating [31].

The fragmentation derived by the end of the Western Roman Empire and the arrival of newcomers to the imperial soil, the role of Christianism in education and culture and several other factors meant a rupture on the ancient education system. Regarding distance learning, it's necessary to pass through a chronological gap of more than one thousand years and continue this narrative at the nineteenth century when the Industrial Revolution implied a new technological paradigm and especially on communications.

If we keep on mind two simple but suggestive definitions of King; Young; Drivere-Richmond \& Schrader [32] of distance learning and distance education, it's possible to trace landmarks, experiences and ways of educational transmission through time and space. Concerning distance learning, these scholars defined it as "improved capabilities in knowledge and/or behaviors as a result of mediated experiences that are constrained by time and/or distance such that the learner does not share the same situation with what is being learned". On the other hand, "distance education is formalized instructional learning where the time/geographic situation constrains learning by not affording inperson contact between student and instructor". Regarding the former notion, these authors consider two categories of distance education: synchronous and asynchronous, depending on the interaction established between tutor and learner [33, p. 212]. There's no room on this paper to deal with every kind of formal and/or informal evidence of learning so the focus will be on just some of the most significant means of distance educative transmission but always insisting on the mediating role of the instruction. That is, a book can provide knowledge but not learning or at least an awareness of bidirectional learning involved between an educator and a student.

As it was mentioned above, the Industrial Revolution sets a milestone regarding communications. The improvement on land transports with the apparition of railroads and the application of internal combustion engine, steamboats, the invention of telegraph and the deep development of post services implied a new time where technology matched with political, economic and social changes of crucial relevance to the immediate future [34]. One of the most important consequences was the emergence of mass society focused on consumption both material and communicational and this new frame obviously got reflected on education [35]. In fact, distance education is an evident sign of this new model.

The development of better postal services implied the appearance of the first correspondence courses and the first experiences come from the United States, as the Illinois Wesleyan University in 1873, the Correspondence University (Ithaca, NY) and the University of Chicago in 1883 illustrate [36, pp. 7-8]. This is the foundation for enormous present distance universities as British Open University or Spanish UNED [37]. Mass media as radio and television have had an enormous impact since their implantation on society. A curious account from 1924 of a tremulous observer describes perfectly the unexpected consequences of the impact of radio in education: "is radio to become a chief arm of education? Will the classroom be abolished, and the child of the future stuffed with facts as he sits at home or even as he walks about the streets with his portable receiving set in his pocket?" [35, p. 54]. Such an apocalyptical view has been frequently announced whenever any new mass media is established in society and although the basic frame of education hasn't changed, the impact is obvious and has supposed an immense chance for education on contexts where custom education wasn't available, as the Australian experience on the use of radio mentioned above or similar experiences show. In fact, the Ebola recent crisis in Africa inflicted a fracture on the educative system of Sierra Leone and the government alongside UNICEF launched a national radio education programme intended to teach almost two million of children across the country [38]. Actually, radio is a remarkable method of teaching because of the apparent simplicity, cheap cost and technical accessibility [39, ch. 6] and it's been used massively on several countries unable to create a traditional educational network or to isolated areas in Africa, South America, Asia and other world territories [40]. In effect, radio has many advantages from the cognitive point of view as this media contributes to the development of imagination and explores oral comprehension [41] and, in spite of the predominance of digital ICT, it still remains as an useful instrument for learning [42]. In comparison with radio, TV educational programmes have developed more frequently on most advanced countries because of the comparatively higher cost [43] since the first experience happened in USA in 1934 and especially after the end of the Second World War 
as $\mathrm{TV}$ is one of the most prominent features of the later consumer society and welfare state [44, p. 30]. In spite of its well deserved ill fame, TV also can be a very fruitful resource for distance education at least if there is a conscious guide on its use [45].

In sum, the impact and the advantages of distance learning are obvious. In the sixties, studies illustrated that Instructional TV implied the same learning results between traditional and distance education and this trend has been reaffirmed in later times [46]. It's not out of the ordinary to see that the biggest university in the world with 2 '7 millions of students is a Chinese distance university named the China Central Radio and TV University. However, the technological advances mean new possibilities of distance learning and although radio, TV, correspondence, educational cassette tapes, and other analogical media aren't today such an important way of education in the age of internet they have their present share of relevance in learning as it's been argued above. However, the digital era proposes worldwide new possibilities as the African Virtual University (AVU) show. This is a pan-African university created originally by the World Bank and placed on Kenya, based on the use of satellite communications [47] [48].

\section{THE ORIGINS OF E-LEARNING}

The development of online training and therefore of learning mathematics through the system e-learning follows the development of internet. From the $60 \mathrm{~s}$ of last century the computer started out as a new tool available to teachers to improve teaching. With the advent of the internet the educational paradigm changes the traditional vertices formed by the physical space. Any content transmitted through the professor and the books as tools [49] will begin to change.

Internet growing has been evolving, improving and creating new tools that have led to areas such as education to evolve in the same way coming to include the network as part of their basic tools. The periodization or the evolution of internet and teaching with the help of computer and network in general is a matter, which with shades, tend to be divided into four or five major periods [49] [50, pp. 214].

\section{A. From the 70 s to middle 80 s}

Until the widespread use of computers, teaching with computer was carried out as a discipline away from the others and in a physical room other than the usual and in which a specialized teacher taught management. This fact allowed to have rooms dedicated only to learning through this tool. In educational and labour levels there were complications such as having to move to a particular place to develop the teaching [4, p. 221]. The background of the e-learning can be found at this time where the learning contents were the last ties between teacher and student, and were called Computer-Based Training, (CBT), Web-Based Training, (WBT) [51, pp. 1] or commoly known as Computer Assisted Teaching (EAO) [52, p. 14].

\section{B. Multimedia (Late 80s-Early 90s)}

The appearance of the Windows computer systems for personal computers was a very important step forward the progress of teaching on the whole. This period is characterized by the marketing of the CDROM, which will gradually replace the 3-1/2 5-1/4 diskettes.. Its ability to provide anytime, anywhere information brought about a quantum leap for multimedia training. The former publishers began to design programs and digital books were sold to educational institutions. These elements called "ToolBooks" were used as multimedia examples, in which it was possible to find topics related to the mathematics, algorithmic simulations, graphs, videos or games [53]. These multimedia first worlds represented a qualitative leap forward in the management of media. This issue allowed the management of the information in only one means system like the image in diverse facets, the audio and the contents. This system was a step forward in the development of teaching contents and mainly on topics like mathematics [54, p. 81].

\section{Emergence of e-learning (Decade 90s)}

The development of computer languages and the evolution of the web pages, among other elements, led to the beginning of the creation of pages on the internet related to mathematical applications. Intranets began to be common instruments in many schools. This improvement was accompanied by the development of specific tools for teaching as were the e-mail, the audio and video, Java applications and HTML. One of the tools most commonly used in these years was the tutoring by e-mail that has reached our days. But the real step forward for the emergence of the e-learning were the first online courses. At the beginning, in a first time in most cases it was only a question of the conversion of different documents to formats like Word, Acrobat or HTML and later to hang them on the web [55, pp.16-17]. Although the solution was not too original it served to give the first step towards the current e-learning, turning these static pages into dynamics offering a more attractive visual aspect, as it was the creation in Fern Universität of the course on line: "Mathematics for Economists" in which the improvements were made as interactive graphics, audio, video and animation, through Flash and Java [53, p.17] [56, pp 8-9]. The natural evolution of the on-line courses completed with the emergence of virtual courses. The forums in which course participants discussed, asked and presented their work, provided a dynamic constructivist bringing the physical classroom to the virtual scope [49]. Next to the forum, email, and the transfer of files became the basis of the current e-learning training. The challenge of this set of learning systems that will be framed within what we call as e-learning will be characterized by the communication through multiple channels, virtuality, the interactivity or the participation among other features [57, p. 32].

\section{The consolidation of e-learning in XXI century}

From models, early XXI century the e-learning has become the model to be developed, based on one in which cognitive factors mature virtual education in which cognitive and metacognitive factors that lacked it, began to consolidate. This is institutionalized through the famous Lisbon Strategy led by the European Council in 2000.

It assumes the need to understand the economic development through science and education as a policy to jointly develop [58, p. 10]. The final step is consolidated with the creation and development of tools and applications called Web 2.0, a term coined by Dale Dougherty and Craig Cline by 2004 [69, p. 367].It entailed the emergence of utilities and tools that the user was able to create their own content [60] [61, p.188]. Users spent "of being passive agents recipients of information to active agents capable of interaction, production and personal involvement in a new level of cooperation and interactive collaboration" $[59$, p. 368].The progress has led us to multiple variants of the teaching of mathematics e-learning. To understand the current situation of multiple existing systems within the e-learning including mathematics teaching García Aretio synthesizes this way (see table 1) [62]. 
TABLE 1

DIFFERENT E-LERNING SYSTEMS INCLUDING MATHEMATICS TEACHING

\begin{tabular}{|c|c|c|}
\hline Synchronous mode & Asynchronous mode & Integrative mode \\
\hline $\begin{array}{l}\text { Courses to } \\
\text { simulate the direct } \\
\text { face interaction } \\
\text { with teachers } \\
\text { and classmates. } \\
\text { Live video, } \\
\text { conversations } \\
\text { between teachers } \\
\text { and students (chat) } \\
\text { and these both } \\
\text { together and voice } \\
\text { conversations, } \\
\text { online assessments, } \\
\text { whiteboards where } \\
\text { everyone can } \\
\text { write or request } \\
\text { clarifications. }\end{array}$ & $\begin{array}{l}\text { The student decides } \\
\text { the pace for learning } \\
\text { and The availability } \\
\text { of time. Student } \\
\text { autonomy grows in } \\
\text { this model. [50, p. } \\
214] \text {. } \\
\text { We have low } \\
\text { resolution video, } \\
\text { evaluations offline, } \\
\text { stored materials that } \\
\text { students can handle } \\
\text { at their personal } \\
\text { convenience. } \\
\text { Comunicación by } \\
\text { e-mail and forums are } \\
\text { usual in this model. }\end{array}$ & $\begin{array}{l}\text { It Uses tools of the two } \\
\text { previous models. [63] } \\
\text { First generation: Adapts } \\
\text { the existing classroom } \\
\text { courses are adapted in } \\
\text { the institution and the } \\
\text { two systems are brought } \\
\text { together. } \\
\text { Second generation: } \\
\text { The courses are created } \\
\text { ad hoc and learning } \\
\text { outcomes are equivalent } \\
\text { to those taught in } \\
\text { classroom format. } \\
\text { Third generation: The } \\
\text { courses are designed to } \\
\text { the needs and training in } \\
\text { the existing society. }\end{array}$ \\
\hline
\end{tabular}

Today there are other emerging models already quoted at the begining of the article but they are still unsophisticated such as the M-Learning, which refers to the use of mobile devices such as PDA, mobile or Windows CE for learning anytime and anywhere [62, p. 426] [64] [65]. Another model is known as Blended-Learning and one of the simplest and most accurate definition describes it as: "Which combines face-to-face and virtual teaching" [66, p. 12] [62, p.418]. It would be a review of the first mixed models based on semi-face contact between teacher and student [67] [68] [69, p. 18] [70].

\section{COLlege AND E-LEARNING}

The evolution of e-learning has taken us to the actual situation in which e-learning is a combination of integrated methods under a model or platform, rather than a homogeneous method. Each entity or institution uses it on a certain way, as you can see in higher education, where online teaching and e-learning are now an essential element. Colleges, although late, started this slow but inexorable process to develop and add this type of teaching. In 2008 a project which resulted in the creation of a White Book of Digital University began. One of the agreements that were pointed out was the responsibility of the Spanish colleges of having an electronic administration at the beginning of 2010 [68].

Since then until recently the e-learning outlook at college has made a qualitative leap forward.

If we follow the data provided by the Ministry of Education (2013) [71]., today the Spanish College System (SCS) is made up by 82 colleges in total, distributed in 348 campus, of those 112 belong to non on-site and special. Of these 82,50 are public and 32 are private.

Since 2001, 14 private colleges have been created, four of them are non on-site colleges, making a total of 6 colleges of this type. These colleges are: Universidad a Distancia de Madrid, Universidad Internacional de la Rioja, Universidad Internacional Valenciana, Universidad Oberta de Catalunya, Universidad Internacional Isabel I de Castilla and Universidad Nacional de Educación a Distancia. All of them offer bachelor's degree and master, although masters are more demanded in general.

On Figure 1 the variable on enrolment is shown in \% for official masters of campus universities and those that use e-learning during the last academic years.

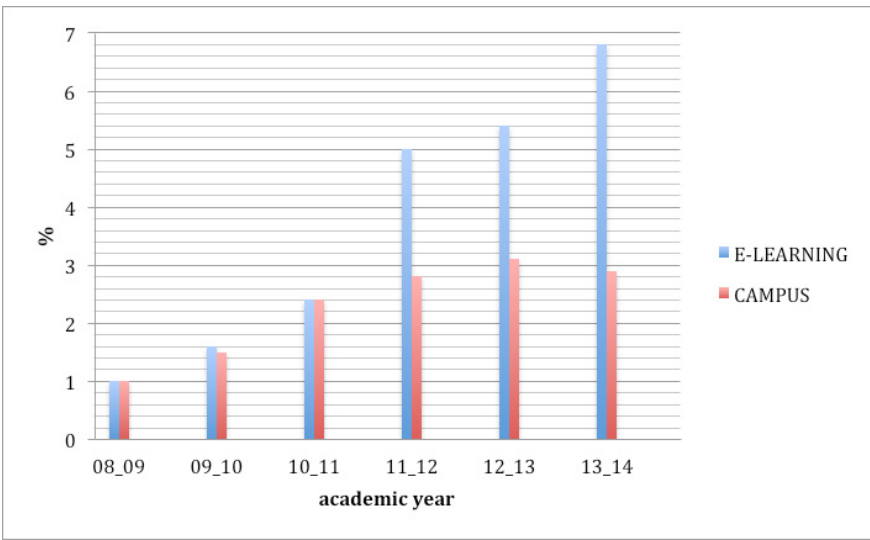

Fig. 1. Variable on enrolment in \%

These results show how the increase in enrolment in e-learning colleges is larger than in campus universities, which is even stalled in the last period.

In the same way if we separate this enrolment between bachelor's degrees and masters, not only an increase is shown in masters enrolment, as it was supposed at the beginning, but also the increase in bachelor's degrees enrolment is clear.

This tendency is observed in Figure 2, where the enrolments in the Universidad Internacional de la Rioja and the Universitat Oberta de Catalunya are analyzed, used as examples because they are two of the private universities that are used as a model because they do all the teaching based on e-learning.

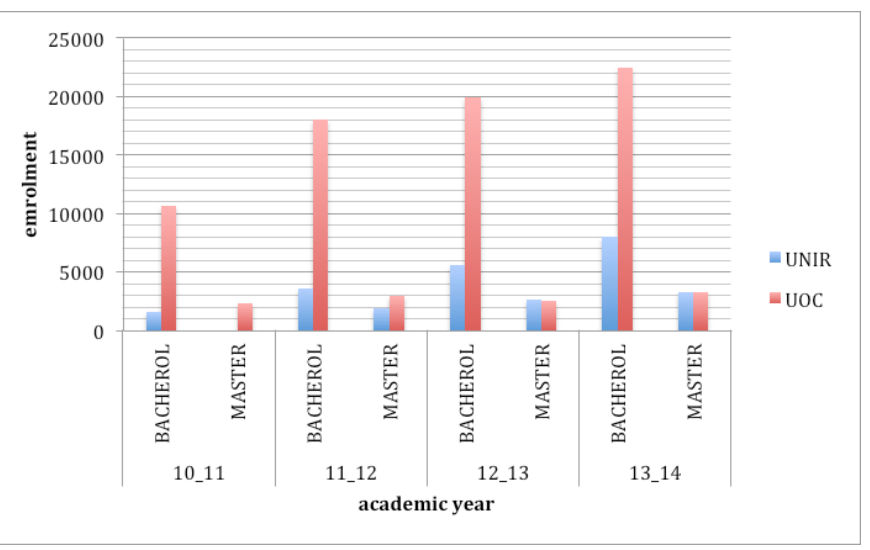

Fig. 2. Increase on enrolment in e-learning method

Enrolments in these colleges are centered in bachelor's degrees and masters in Social Studies, although gradually they are including bachelor's degrees and masters where science and technology are more prominent.

Also, it is interesting to emphasize that in high school in the last years the number of students enrolled that use this method of learning is also increasing, reaching 55,000 enrolled students in high school in 2014 and more than 1,500 in CIDEAD program, numbers that are increasing year by year.

\section{Maths Competencies}

Although the introduction of competences in the school system is relatively new, if we examine what math competence is, besides being a complex term and hard to define [72], we will see that it has substantially changed along the years, because it is no longer associated with the mechanical practice of some skills and routines. That is to 
say, not only is required the rote learning of the discipline and control algorithms, formulas, and procedures [73].

Although the authors and institutions that have tried to identify and enclose the term and concept of" math competence" are numerous [74] [75] [76], the most relevant author defines it as "the capacity to understand, judge, do and use math in a variety of contexts within mathematics and extra mathematics $[75$, p. 22] .

This author [75] goes further than this simple definition and categorizes it establishing two large groups of capacities or mathematical skills that have to take place in this competence: skills to establish questions and answer mathematical questions and with mathematics, and skills to use mathematical language and mathematical tools.

Based on the grouping we created before we have created the following table (table 2), where the categories that could be established on each group are shown [72].

TABLE: 2

GROUPS OF CAPACITIES OR MATHEMATICAL SKILLS

Capacity of formulate and

answer mathematical questions and with mathematics

Capacity of manage mathematical tools and language

\begin{tabular}{|l|l|}
\hline Think mathematically & $\begin{array}{l}\text { Represent mathematical objects and } \\
\text { situations }\end{array}$ \\
\hline $\begin{array}{l}\text { Set out and solve mathematical } \\
\text { problems }\end{array}$ & $\begin{array}{l}\text { Use mathematical symbols and } \\
\text { formalities }\end{array}$ \\
\hline Model mathematically & $\begin{array}{l}\text { Communicate with mathematics } \\
\text { and about mathematics }\end{array}$ \\
\hline Reason mathematically & $\begin{array}{l}\text { Use mathematical tools and } \\
\text { resources }\end{array}$ \\
\hline
\end{tabular}

The OCDE [77], on the PISAreport of 2012, to establish mathematical competence, uses Niss's definition [75] and also the categorization that he does of it, and points out that this capacity of the individual must include "the mathematical reasoning and the mathematical use of concepts, procedures, data, and tools that are needed to describe, explain and predict phenomena, as well as to recognize the role that mathematics have in society.

Although at the beginning up to eight mathematical capacities or skills are established [75], as we said before, the OCDE [77] regroups them in seven:

- Communication: in this skill, identify and understand the situation described in a problem is included, as well as the subsequent presentation of solutions.

- Mathematization: this term makes reference to the description of the main mathematical activities involved in a problem. What makes that a defined problem in the real world becomes into a strictly mathematical way.

- Representation: charts, tables, diagrams, images, equations, formulas, and specific materials.

- Reasoning and mathematical argument.

- Use of operations and symbolic, formal and technical language in a mathematical context.

- Strategy design to solve problems: selection or design of a plan to use mathematics to solve problems.

- Use of mathematical tools.

As it can be seen, this definition includes in an explicit way the use of mathematical tools, understanding as these the physical and digital equipments, computer programs, and calculation tools [77]. This has been created in order to have competent citizens that will use mathematical tools on e-learning regularly in their work environment as well as in their daily life [78].

\section{VIRTUAL LEARNING ENVIRONMENTS, PLATFORM AND MATH SOFTWARE}

The introduction of competences in the Spanish educational system by the LOE [79] and after that, with the LOMCE [80], as well as the implementation of the European System of Higher Education in 2010 [81], have caused numerous methodological challenges in every educational level. If we focus on college education, specifically in higher education in mathematics and statistics as cross-curricular subjects in numerous bachelor's degrees and masters that are offered, we can observe that those challenges are mainly focused on the Internet implementation, specialized software, etc., and in the interest of the institutions to reinforce a diligent approach of these subjects, in order to add the professional competences linked to these knowledge areas [82]. Besides, the National Council of Teachers of Mathematics [83], emphasizes the importance of technology in the process of teaching and learning of mathematics and similar disciplines, and they include it in their standards.

After all the changes that the educational system faces it is necessary to design more effective learning environments and in agreement with actual demands [73]. It is in this context where the technologies of information and education arise as the main agent of change, due to their high amount of interdisciplinary nature, as well as the acquisition of the competence based on the technological, digital, and audiovisual literacy [84].

The use of these technological resources must not be reduced to just a modernization of the educational environment, they have to fulfill a specific function in the teaching-learning process. That is to say, the use of them must be ruled by an adequate and educational model, having an impact on methodology and in the use of technologies, not only in the knowledge of a technological tool. This means that we do not talk only about the ICT, but also these ICT that are effective in the teaching-learning process, that is to say, the technologies of learning and knowledge [85].

The introduction in the classrooms of the ICT and especially of Internet has created the learning virtual spaces, that are online platforms where the process of teaching-learning can be developed using the cooperative and / or collaborative learning [86]. It is necessary to say that not all the educational online platforms have to be considered as learning virtual spaces, because they not only have to encourage the student using different activities to build knowledge towards thinking, reasoning, and own reflection. Besides, the discussion and reflection with colleagues is also necessary [73]. In certain occasions this can be a problem, because sometimes this collaboration between students does not happen naturally, so the teacher has to be the one who encourages participation [87].

In the case of the disciplines related to the area of mathematics, besides the appearance of specific learning virtual spaces, and certain platforms, is joined by the widespread use of statistical and mathematical software that helps experimenting with concepts and techniques advanced, at the same time ensures a concept applied in this discipline, both in its scope, as transversely [88]. This software can be used both in virtual learning spaces, such as platforms, or just in isolation. Regardless of the form of use provides better visualization of mathematical and statistical concepts, an approach to mathematicalstatistical knowledge by experimenting in different scenarios, the development of students' critical thinking, bridging the gap between theory and practice (allowing solving real problems), and of course represent a reduction of mechanical work [89]. Therefore, although the students to achieve certain math skills is a complex task, yes these tools, facilitate, at first their achievement. Although keep in mind that 
to integrate digital technology, students must develop skills related to the use of ICT ] [87]. In fact, he re-emphasized the PISA 2012 report [77] is specified that at the time of the assessment and not only are we considering math skills themselves, but also skills that cover aspects of mathematics and ICT, namely, that to master knowledge concerning needed to perform mathematical activities with the help of a technological device; and ICT skills.

\section{PlatFormS AND SPECIFIC MATHEMATICAL SOFTWARE}

\section{A. Some nonspecific platforms}

\section{MOODLE:}

\section{https://moodle.org/?lang=es}

It is a free distribution platform that allows you to create virtual learning environments through which to create and manage courses and create online learning communities. Numerous publications that test this platform as a virtual learning environment subjects of mathematics area [87] [90]. A priori, one of the problems that can make this platform is that your text editor does not allow the inclusion of mathematical symbols, however it is possible to integrate LaTeX filters that enables the interpretation of LaTeX code embedded in the text [90].

\section{BLACKBOARD:}

http://es.blackboard.com/sites/international/globalmaster/

Blackboard Academic Suite is a platform that enables the management and operation of courses for virtual learning environments. It is designed to facilitate and encourage the development of educational innovation.

\section{SAKAI:}

\section{https://sakaiproject.org}

It is a joint project of the University of Michigan, Indiana University, the Massachusetts Institute of Technology and Stanford University, the Open Knowledge Initiative (OKI) and uPortal consortium. It is based on the development of open source educational software to create virtual environments for collaborative learning in the field of higher education.

\section{B. Specific platforms for mathematics}

\section{MUMIE:}

\section{https://www.mumie.net}

It is the result of a joint project of cooperation between major European universities. It is an e-learning platform open to learning and teaching of mathematics and computer code. Both the courses and course materials are easily adjusted to any level of education. Have become virtual learning environments using social networks and wikis, to facilitate and encourage the creation of new content.

\section{PROJECT DESCARTES}

\section{http://proyectodescartes.org/descartescms/index.php/latest/}

It is a project developed by the Spanish government in the field of non-university education. Contains teaching materials for math, easily controlled by the teacher and simple to use by students. It is based on the contents of the official curriculum and allows the possibility of using active, creative and cooperative, while personal attention methodologies and, therefore, a good management attention to diversity.

In addition, the following table (table 3 ) lists specific mathematical software for different areas within the mathematical discipline, which can be used both in virtual learning environments independently as shown.
TABLE 3:

SPECIFIC MATHEMATICAL SOFTWARE

\begin{tabular}{|l|l|}
\hline Area & Software name and URL addres \\
\hline \multirow{5}{*}{$\begin{array}{l}\text { Computational } \\
\text { Algebra }\end{array}$} & $\begin{array}{l}\text { MÁXIMA } \\
\text { http://maxima.sourceforge.net/es/ }\end{array}$ \\
\cline { 2 - 3 } & $\begin{array}{l}\text { SAGE } \\
\text { http://www.sagemath.org/es/ }\end{array}$ \\
\cline { 2 - 3 } Numerical & $\begin{array}{l}\text { YACAS } \\
\text { http://yacas.sourceforge.net/homepage.html }\end{array}$ \\
\cline { 2 - 3 } Analysis & $\begin{array}{l}\text { MACULAY2 } \\
\text { http://www.math.uiuc.edu/Macaulay2/ }\end{array}$ \\
\hline \multirow{5}{*}{ Plotters } & $\begin{array}{l}\text { GNU Octave } \\
\text { https://www.gnu.org/software/octave/ }\end{array}$ \\
\cline { 2 - 3 } & $\begin{array}{l}\text { SCILAB } \\
\text { http://www.scilab.org }\end{array}$ \\
\hline \multirow{5}{*}{$\begin{array}{l}\text { Statistical } \\
\text { Calculation }\end{array}$} & $\begin{array}{l}\text { GNUPLOT } \\
\text { http://www.gnuplot.info }\end{array}$ \\
\cline { 2 - 3 } & $\begin{array}{l}\text { LABPLOT } \\
\text { http://labplot.sourceforge.net }\end{array}$ \\
\cline { 2 - 3 } & $\begin{array}{l}\text { SCIGRAPHICA } \\
\text { http://scigraphica.sourceforge.net }\end{array}$ \\
\hline & $\begin{array}{l}\text { SPSS } \\
\text { http://www-01.ibm.com/software/es/analytics/spss/ }\end{array}$ \\
\cline { 2 - 3 } & $\begin{array}{l}\text { R-PROYECT } \\
\text { http://www.r-project.org }\end{array}$ \\
\hline
\end{tabular}

\section{REFERENCES}

[1] J. Fernández-Mayoralas, "Matemáticas de la Historia (o de cómo Clio, celosa de Urania, soñaba con ser de mayor una ciencia exacta)", Memoria y civilización, vol. 3, pp. 275-309, 2000.

[2] C. Quinn, C. Mobile magic: Think different by design. Ciclo de conferencias de la Escuela de Graduados en Educación y Centro de Innov@te del Tecnológico de Monterrey, 18 de septiembre, quoted by C. Izarra. (2010, July). Mobile Learning. C.J.Blog [Online]. Availeable: https://carolinaizarra.wordpress.com/81-2/

[3] H. Izagirre, Los sótanos del mundo. Bilbao: Elea, 2007.

[4] N. Rodríguez, "La educación a distancia en el contexto de la globalización tecnológica y socio-cultural”, Eikasia: revista de filosofia, n 57, pp. 217 230, 2014.

[5] H. Hernández, "La educación virtual en el siglo XXI", Investigación Educativa Duranguense, $\mathrm{n}^{\circ}$ 13, pp. 55-59, 2013.

[6] PLE. (2014, May 21). Entorno Personal de Aprendizaje. PLE Blog [Online]. Availeable: http://ple.blogspot.es/

[7] A. Brigham and F. Ramos, "Avaliação da metodologia b-Learning no Mestrado Multimédia em Educação (edição 2007-2009) da Universidade de Aveiro", Educação, Formação \& Tecnologias, vol. 3, nº 2, pp. 71-81, 2010.

[8] Y. Salazar and F. Rojas, "La motivación, la experticia tecnológica y el acceso a recursos informáticos y su relación con modalidades de enseñanza virtuales", Anales de la Universidad Metropolitana, vol. 10, nº 2, pp. 75-92, 2010.

[9] O. Casquero, J. Portillo, R. Ovelar, J. Mª Romo and M. Benito, "Strategy approach for eLearning 2.0 deployment in Universities", Digital Education Review, $\mathrm{n}^{\circ}$ 18, Decem. 2010.

[10] Y. Ramírez and J. Peña, "La Web 3.0 como Herramienta de Apoyo para la Educación a Distancia", Etic@net, nº 10, Jun. 2011.

[11] A. Zanela, N. Reinhard, E. Schlemmer and J. W. Barbosa, "M-Learning (mobile learning) in practice: a training experience with IT professionals", JISTEM-Journal of Information Systems and Technology Management, vol. 7, nº 2, pp. 261-280, 2010.

[12] F. J. Ramos, "Plataforma mlearning como apoyo a las actividades de enseñanza aprendizaje en la física mecánica", Prospectiva, vol. 10, $\mathrm{n}^{\circ} 2$, pp. 94-101, Jul.-Decem. 2012.

[13] J. C. Sánchez Prieto, S. Olmos and Fco. J. García, "Understanding mobile learning: devices, pedagogical implications and research lines", Teoría de la Educación: Educación y Cultura en la Sociedad de la Información, vol. 15, no 1, pp. 20-42, 2014. 
[14] M. A. Rodrigo and C. de Castro, "La información digital actual, un nuevo modelo de contenido educativo para un entorno de aprendizaje ubicuo", RED: Revista de Educación a Distancia, nº 39, 16 pp., 2013.

[15] H. A. Villa, Fco. J. Tapia and C. A. López, "Aprendizaje ubicuo en la enseñanza de las matemáticas", Revista Estudios Culturales, n ${ }^{\circ}$ 5, pp. 123 $136,2010$.

[16] A.-R. Bartolomé and K. Steffens, "¿Son los MOOC una alternativa de aprendizaje?", Comunicar: Revista científica iberoamericana de comunicación y educación, $\mathrm{n}^{\circ}$ 44, pp. 91-99, 2015.

[17] A. Fidalgo, Ma. L. Sein-Echaluce, O. Borrás and Fco. J. García, "Educación en abierto: integración de un MOOC con una asignatura académica", Teoría de la Educación: Educación y Cultura en la Sociedad de la Información, vol. 15, nº 3, pp. 233-255, 2014.

[18] J. Cabero-Almenara and $\mathrm{M}^{\mathrm{a}} \mathrm{C}$. Llorente, "Las tipologías de MOOC: su diseño e implicaciones educativas", Profesorado: Revista de curriculum y formación del profesorado, vol. 18, no 1, pp. 13-26, 2014.

[19] J. Valverde, "MOOC: una visión crítica desde las ciencias de la educación", Profesorado: Revista de curriculum y formación del profesorado, vol. 18, $\mathrm{n}^{\circ}$ 1, pp. 93-111, 2014.

[20] $M^{a}$. P. Prendes and $M^{a}$ M. Sánchez, "Arquímedes y la tecnología educativa: un análisis crítico en torno a los MOOC", Revista interuniversitaria de formación del profesorado, $\mathrm{n}^{\circ}$ 79, pp. 29-50, 2014.

[21] J. Gómez, "El fenómeno MOOC y la universalidad de la cultura: las nuevas fronteras de la Educación Superior", Profesorado: Revista de curriculum y formación del profesorado, vol. 18, nº 1, pp. 73-91, 2014.

[22] J. Díaz, "Modelos pedagógicos en educación a distancia", REDHECS: Revista electrónica de Humanidades, Educación y Comunicación Social, $\mathrm{n}^{\mathrm{o}}$ 12, pp. 86-113, 2012.

[23] B. Duvillié, Sur les traces de l'Homo mathematicus. Les mathématiques avant Euclide. Mésopotamie, Egypte, Gréce. Paris: Ellipses, 1999.

[24] On this notion, see the thinking of the remarkable Padre Sarmiento, Spanish scholar from the XVIIIth century in U. Pérez Rodríguez, M. Álvarez Lires, and J. Lillo Beviá "Fray Martín Sarmiento y la Educación Científica. II. La enseñanza de las matemáticas y la Astronomía", in Revista de investigación en educación vol. 7, pp. 37-49, 2010.

[25] Plato Leg. 819c.

[26] On mathematics in Antiquity, see e.g.: F. Lasserre, The birth of mathematics in the age of Plato. London: Hutchinson, 1964.

[27] S. Bochner, The role of mathematics in the rise of science. Princeton: Princeton University Press, 1966.

[28] G. E. R. Lloyd, Disciplines in the making. Oxford: Oxford University Press, 2009, who interestingly argues about the origin of mathematics in ancient Greece and China.

[29] J. Muir, Life and letters in the ancient Greek world. London: Routledge.

[30] On science field: D. R. Langslow, "The epistula in ancient scientific and technical literatura, with special reference to medicine", in Ancient letters. Classical and Late Antique epistolography, R. Morello and A. D. Morrison, Eds. Oxford: Oxford University Press, 2007, pp. 211-234.

[31] As in, e.g., Synesius ep. 15 and 124.

[32] F. B. King, M. F. Young, K. Drivere-Richmond, and P. G. Schrader, P. G., "Defining Distance Learning and Distance Education", in Educational Technology Review, vol. 9 n. 1, 2001 [online]. Available: http://www. editlib.org/p/17786/

[33] See also A. Conde, cited in M. B. Tellería, "Educación y nuevas tecnologías. Educación a distancia y educación virtual", in Revista de Teoría y Didáctica de las Ciencias Sociales, vol. 9, pp. 209-222, 2004.

[34] E. J. Hobsbawn, Industry and Empire. From 1750 to the present day. London: Penguin 1999.

[35] S. J. Baran and D. K. Davis, Mass Communication Theory: Foundations, Ferment, and Future. Boston: Cengage Learning, 2011.

[36] G. A. Berg, Why distance learning? Higher education administrative practices. Westport: American Council on Education, 2002.

[37] On this kind of universities, see J. S. Daniel, Mega-universities and knowledge media. Technology strategies for higher education. London: Routledge, 2006.

[38] Y. Romero, "In Sierra Leone, getting back to school - on the airwaves", 2015. Available: http://www.unicef.org/infobycountry/sierraleone_76352. html. Accesed on: 03/23/2015

[39] A. Singhai and E. Rogers, Entertainment-Education: A communication strategy for social change. London: Routledge.
[40] P. O'Shea and S. Richmond, Radio Education. A Review of the Literature. WorldAgInfo. 21st century agricultural education and Information system project's First Kilometre literature reviews. Available: http://www. worldaginfo.org/files/Radio\%20Education.pdf. Accesed on: 03/23/2015

[41] E. Rodero, "Educar a través de la radio", in Signo y Pensamiento, vol. 52, pp 97-10, 2008.

[42] N. Szyszko and Z. Cataldi, "La radio en la escuela media como agente participativo", in Quaderns digitals: Revista de Nuevas Tecnologías y Sociedad, vol. 61, pp. 1-15, 2010.

[43] J. A. Brown, Television 'Critical viewing skills' education: major media literacy projects in the United States and selected countries. London: Routledge, 2009.

[44] M. G. Moore and Greg Kearsley, Distance Education: A systems view of online learning. Belmont: Wadsworth, 2012.

[45] C. Medrano Samaniego, "Televisión y educación: del entretenimiento al aprendizaje", in Teoría de la Educación, vol. 20, pp. 205-224, 2009.

[46] F. Saba, "Research in Distance Education: A Status Report", in International Review of Research in Open and Distance Learning, vol. 1 n. 1, 2000 [online]. Available: http://www.irrodl.org/index.php/irrodl/ article/view/4/337

[47] M. N. Juma, Kenyatta University - African Virtual University. An evolution of an existing institution, Kenya. UNESCO, 2006 [online]. Available: http://www.unesco.org/iiep/virtualuniversity/media/document/ Ch10_AVU_Juma.pdf.

[48] A critic view in M. N. Amutabia \& M. O. Oketch, "Experimenting in distance education: the African Virtual University (AVU) and the paradox of the World Bank in Kenya", in International Journal of Educational Development, vol. 23 n. 1, pp. 57-73, 2003.

[49] J.M.Santamans, El mercado global del e-learning. On Line Business School, 2015.

[50] M.B. Tellería, "Educación y nuevas tecnologías. Educación a Distancia y Educación Virtual" in Revista de Teoría y Didáctica de las Ciencias Sociales, núm. 9, pp. 209-222, 2004.

[51] Guía Práctica para la elaboración de contenidos de e-learning en base a estándares tecnológicos y pedagógicos, Servicio Andaluz de Empleo, 2005.

[52] L. García, "Historia de la Educación a distancia" in Revista Iberoamericana de educación a distancia, vol. 2, no 1, pp. 8-27, 1999.

[53] W.Laaser, "De la unidad didáctica a la web colaborativa. La evolución de la apropiación de los medios en el contexto de la educación superior" in VEsC, Año 2, no 3, pp. 11-27, 2011.

[54] A.Moron, "Multimedia en Educación" in Comunicar, $\mathrm{n}^{\circ}$ 3, 1994.

[55] See also W.Rödder in W.Laaser, "De la unidad didáctica a la web colaborativa. La evolución de la apropiación de los medios en el contexto de la educación superior" in VEsC, Año 2, nº 3, pp. 11-27, 2011.

[56] M.J. Rosenberg, E-learning: Strategies for delivering knowledge in the digital era. New-York: Mc-Graw-Hill, 2001.

[57] P. Colas, "Internet y aprendizaje en la sociedad del conocimiento" in Comunicar, $\mathrm{n}^{\mathrm{o}}$ 20, pp. 31-15, 2003.

[58] J.M. Valle, "La política educativa de la Unión Europea en el laberinto del Minotauro" in Foro de educación, 12, pp. 7-23, 2010.

[59] A. De Juanas and A. Diestro, "Empleo de los medios sociales en educación superior: una nueva competencia en ciernes" in Revista de Docencia Univeristaria, vol.10 (2), pp 365-379, 2012.

[60] T. O'Reilly, What Is Web 2.0? Design Patterns and Business Models for the Next Generation of Software, 2005 [online]. Avaible: http://www. oreilly.com/pub/a/web2/archive/what-is-web-20.html

[61] F.J. García Peñalvo, "La universidad de la próxima década: la universidad digital" in Universidad y desarrollo social de la web (pp. 181-197). Washington DC : Editandum, pp. 182-197, 2011.

[62] L. García, "Viejos y nuevos modelos de educación a distancia" in Bordón Madrid, vol 56, 3-4, pp 409-429, 2004.

[63] See also J.Darby cited in L. García, "Viejos y nuevos modelos de educación a distancia" in Bordón Madrid, vol. 56, 3-4, pp 409-429, 2004.

[64] See also Harris cited in L. García, "Viejos y nuevos modelos de educación a distancia" in Bordón Madrid, vol. 56, 3-4, pp 409-429, 2004.

[65] See also Lehner \& Nosekabe cited in L. García, "Viejos y nuevos modelos de educación a distancia" in Bordón Madrid, vol. 56, 3-4, pp 409-429, 2004.

[66] See also Marsh cited in A. Bartolomé, "Blended Learning. Conceptos básicos. Píxel-Bit" in Revista de Medios y Educación, 23, pp. 7-20, 2004. 
[67] M.W. Brodsky, Four Blended Learning Blunders and How to Avoid Them. Learning Circuits, Noviembre 2003 [online]. Avaible: https://electromeet. com/library/Four_blended_e-learning_blunders.doc

[68] M. Brennan, "Blended Learning and Business Change" in Chief Learning Officer Magazine, 2004 [online]. Avaible: http://www.clomedia.com/ articles/blended_learning_and_business_change

[69] See also G.Marsh cited in A. Bartolomé, "Blended Learning. Conceptos básicos. Píxel-Bit" in Revista de Medios y Educación, 23, pp. 7-20, 2004.

[70] See also Laviña and Mengual cited in F.J. García Peñalvo, "La universidad de la próxima década: la universidad digital" in Universidad y desarrollo social de la web (pp. 181-197). Washington DC : Editandum, pp. 182-197, 2011.

[71] Ministerio de Educación, Cultura y deporte. Datos Básicos del Sistema Universitario Español. Curso 2013/2014. Catálogo de publicaciones del Ministerio[online] Avaible: www.mecd.gob.es

[72] G. Albano. "Conocimientos, destrezas y competencias: un modelo para aprender matemáticas en un entorno virtual". RUSC., vol. $9 \mathrm{n}^{\circ} 1$ pp. $115-$ 129. 2012.

[73] S. Inzunsa. "Entornos virtuales e aprendizaje. Un enfoque alternativo para la enseñanza y aprendizaje de la inferencia estadística". RMIE, vol. $15, \mathrm{n}^{\circ}$ 45, pp. 423-452. 2010

[74] P. Abrantes. "Mathematical competence for all: Options, implications and obstacles". Educational Studies in Mathematics, no 47, pp. 125-143. 2001.

[75] M. Niss. "Mathematical comptencies and the leraning of mathematics: the Danish Kom project". En : A Gagatsis; S Papastavridis (eds). Proceeding of the 3rd Mediterranean Conference on Mathematical Education. Atenas: Hellenic Mathematical Society. pp. 115-124. 2003.

[76] F. Weinert. "Concept of competence: a conceptual clarification".In: D.Rychen; L.Salgenik (eds). Defining and electing key competencies. Seattle, Toronto, Bern, Göttingen: Hogrefe \& Huber Publishers.

[77] OCDE (2012). Informe PISA 2012 .[online] Avaible: http://www.oecd. org/pisa.

[78] C. Hoyles, A. Wolf, S. Molyneux-Hodgson \& P. Kent. "Mathematical skills in the workplace". London: The Science, Technology and Mathematics Council. 2002 [online] Avaible: www. ioe. ac. uk/tlrp/technomaths/ skills2002.

[79] Ley Orgánica 2/2006, de 3 de mayo, de Educación.

[80] Ley Orgánica 8/2013, de 9 de diciembre, para la mejora de la calidad educativa.

[81] http://www.eees.es/

[82] C. Steegman, M.A. Huertas, A.A. Juan, M. Prat. "E-learning de las asignaturas del ámbito matemático-estadístico en las universidades españolas: oportunidades, retos, estado actual y tendencias". RUSC, vol. 5, nº 2 . pp.1-14 2008.

[83] NCTM. "Principios y estándares para la Educación Matemática". Sevilla: Sociedad Andaluza de Educación Matemática. 2003

[84] J.G. Morcillo, E. García García,, M. López García \& N.E. Mejías Tirado. "Los laboratorios virtuales en la Enseñanza de las Ciencias de la Tierra: los terremotos". Enseñanza de las Ciencias de la Tierra, 14(2), pp. 150156. 2006.

[85] R. Lozano "De las TIC a las TAC: tecnologías del aprendizaje y el conocimiento". Anuario ThinkEPI, 5, pp. 45-47. 2011

[86] H.S. Pérez, S.R. Fernández \& C.G. Braojos, C. G. "Metodologías que optimizan la comunicación en entornos de aprendizaje virtual. Comunicar: Revista científica iberoamericana de comunicación y educación, $\mathrm{n}^{\mathrm{0}} 34$, pp.163-171. 2010.

[87] M.L. García \& A.A. Benítez "Competencias matemáticas desarrolladas en ambientes virtuales de Aprendizaje: el caso de MOODLE”. Form. Univ. vol. $4, \mathrm{n}^{\circ} 3$, pp. 2011

[88] C. Córceles, M.A. Huertas, A. Juan, C. Serrat, \& C. Steegmann. Math on-line education: State of the Art, Experiences and Challenges. Abstract in Proceedings of the 2006 International Congress of Mathematicians, pp. 578-579. 2006

[89] F. Alonso, G. Rodríguez, A. Villa. "New challenges, new approaches: A new way to teach Mathematics in Engineering" In: International Conference on Engineering Education - ICEE 2007 (Septiembre: Coimbra, Portugal) [comunicación en línea]. [[online]. Available:http:// icee2007.dei.uc.pt/proceedings/papers/122.pdf

[90] R. Pérez, J. Rojas \& G. Paulí "Algunas experiencias didácticas en el entorno de la plataforma Moodle" Revista de informática educativa y medios audiovisuales vol. 5, $\mathrm{n}^{\circ}$ 10, pp. 1-10. 2008



David Álvarez Jiménez has a Ph.D. in Ancient History by Universidad Complutense de Madrid with a thesis titled "Piracy in Late Antiquity". His main research topics are social, political and military history of the Later Roman Empire and sub-Roman kingdoms. He has made research stays in University of Oxford and Paris-X-Nanterre. He is the chairman of Herakleion, e-journal on ancient history and archaeology of the Mediterranean (www.herakleion.es) and member of Asociación Barbaricvm. Currently he is assistant teacher in Universidad Internacional de La Rioja (UNIR), at the Master in Teaching and Learning (MTL). Member of UNIR Research group GdI-16 DHISDI: Didáctica de la historia en la sociedad digital, where I work on national identities in school textbooks.

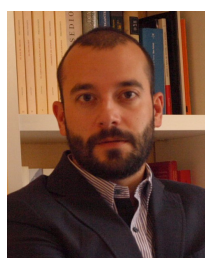

Daniel Moreno Mediavilla, Professor at the International University of La Rioja. PhD in Chemistry (Organic Chemistry) by the University of Burgos. He has pursued his research in Organic Chemistry: chemical sensor and fluorimetric and colorimetric probes. $\mathrm{He}$ is the author of several international in the field of macromolecular compounds. He has participated in more than 20 national and international congresses, conferences and seminars. At present, his research is focusing in expectations and forms of ownership of technology by compulsory secondary education teachers, with the research group "El Quehacer Educativo como acción" (GdI-05 EDUCACCION), at the Universidad Internacional de la Rioja.

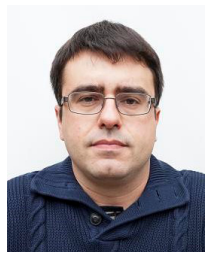

Pablo M. Orduna Portús, has a PhD in History (Early Modern Period) by the University of Navarre and is qualified and with a degree in Diploma in Basque Studies (Ethnographic Area) by the same academic centre. Likewise, it has worked like educational at said institution and at the University of Santa Barbara, California (UCSB). At present, he's Professor at the Universidad Internacional de la Rioja applying knowledge in a practical way of new scholastic methods, also is member of the research group GdI-01 CRDH. He has realized works like researcher (scholarships) by Spanish National Research Council (CSIC) and by the José Miguel de Barandiarán Foundation. He enjoyed a stay of research at the Center for Basque Studies (University of Nevada, Reno). Actually, he belongs to different associations, so was and is an active member inside the academic environment, research and cultural management. He has published and took an active part in different projects, books and articles and given conferences about OER, MOOC, VM, History, Ethnography, Anthropology and Cultural Heritage.

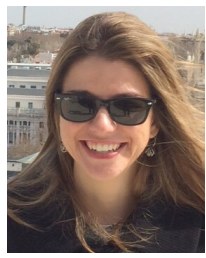

Virginia Pascual López, Professor at the International University of La Rioja. European PhD in Biology (Plant ecology) by the University of Málaga. She is co- author of several international papers in the field plant ecology of semiarid ecosystems and high mountains. She has participated in national and international research projects. Also, she has worked like a science teacher in High school, applying new methodologies and technologies in the teaching-learning process. Nowadays, her research is focusing in neurosciences and metacognition, with the research group "Applied Metacognition" at the Universidad Internacional de la Rioja (GdI-11: GIMA).

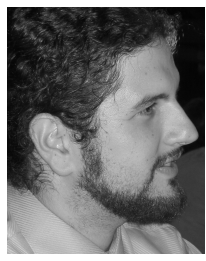

Fco.Javier San Vicente Vicente has a Ph.D. in Arqueología by Universidad Salamanca with a thesis titled "Análisis cultural del territorio a través del patrimonio etnológico. Tutela, gestión y desarrollo: el noroeste de La Ramajería (Salamanca)". He has won various scholarships and financial aid for research institutions such as the Museum of Ethnography in Castile and Leon or Villarlar the Foundation.

His main research topics are management of cultural heritage, cataloging of the ethnological heritage, socialization and education of the cultural heritage and urban archeology. He has participated in, directed and coordinated exhibitions, conferences, courses and projects of education and socialization of the cultural heritage through the new technologies in rural areas. He has published and took an active part in different congress, books and articles. Currently he is professor external collaborator in Universidad Internacional de La Rioja (UNIR), at the Master in Teaching and Learning (MTL). He is a member of various associations that promote advocacy and education of the cultural heritage and is vice president of the Association of Archaeologists of Castile and Leon. 